\title{
The Influence of User Efficacy and Expectation on Actual System Use
}

\author{
Olusola I. Akinbobola and Akinniyi A. Adeleke \\ Redeemer's University, Redemption City, Ogun State, Nigeria
}

solaakinbobola@yahoo.co.uk erinfaith10@yahoo.com

\begin{abstract}
Many studies have been done on human-computer interaction (HCI), but there is a dearth of studies on the mandatory actual system use in Nigerian university libraries. The relationship between sources of computer self-efficacy and outcome expectancy on actual system use was assessed, based on social cognitive theory, by surveying mandatory use of KOHA version 3.0.1 integrated library management software. The questionnaire survey was conducted on 61 library personnel in 5 private Nigerian universities. Data were analyzed by multiple regression analysis and Pearson product moment correlation. The structural model accounted for $48 \%$ of variance in actual system use, $80 \%$ in computer self-efficacy, and $19 \%$ in outcome expectancy. This study suggests that usability, supportive management, and computer self-efficacy are important determinants of actual system use of KOHA software. Self-efficacy had influence on outcome expectancy. The implication of applying the social cognitive theory to actual system use of KOHA software by library personnel is discussed.
\end{abstract}

Keywords: Usability, self-efficacy, outcome expectancy, social cognitive theory, KOHA software.

\section{Introduction}

Actual system use generates research interest in human computer interaction (HCI), especially in a non-voluntary environment. Actual system use is system usage in which the user has no choice but to use the system in a mandatory-use environment. Prediction of behaviors is therefore not based on intention to use the system (Rawstorne, Jayasuriya \& Caputi 1998; 2000). The occurrence of actual system use involves interaction among a user, a system, and a task (BurtonJones \& Straub, 2006; Barki, Titah \& Boffo, 2007). Actual system use can be characterized in terms of three behaviors, namely, technology interaction behavior, task-technology adaptation behavior, and individual adaptation behavior.

Actual system use is a construct that has three dimensions which are users' immersion, reinvent-

Material published as part of this publication, either on-line or in print, is copyrighted by the Informing Science Institute. Permission to make digital or paper copy of part or all of these works for personal or classroom use is granted without fee provided that the copies are not made or distributed for profit or commercial advantage AND that copies 1) bear this notice in full and 2) give the full citation on the first page. It is permissible to abstract these works so long as credit is given. To copy in all other cases or to republish or to post on a server or to redistribute to lists requires specific permission and payment of a fee. Contact Publisher@InformingScience.org to request redistribution permission. tion, and learning. Immersion measures the activity between the user and the system (Burton-Jones \& Straub, 2006). It is based on technology interaction behavior, and is the extent to which the individual can set aside other concerns related to his or her ability to focus on and perform the required specific task while using the system. 
Reinvention is based on task-technology adaptation behavior, or task-technology fit (Barki, Titah $\&$ Boffo, 2007). Task-technology adaptation behavior includes all acts such as modifying or changing information system for its use in the organization. Reinvention reflects the extent to which the user changes an innovation following its original development (Rice \& Rogers, 1980). Reinvention then is the extent of effort that the user puts into the development of the fit between the task and the system to improve his or her performance.

Learning, as an additional dimension of actual system use, is based on individual adaptation behavior (Barki, Titah \& Boffo, 2007). Learning is the degree to which users communicate with each other and search for information in order to improve their knowledge and skill on the system. Individual adaptation behavior represents behavioral changes that the individual makes to himself in order to adapt to the system. Such self-modification behaviors include learning activity and interaction between individuals and the system (Beaudry \& Pinsonneault, 2005). As users learn how to use the new system, they can apply new ways of performing their tasks and exchanging information with each other.

Of particular interest is library personnel's use of information management systems. Librarians play a vital role in ensuring optimal use of available information systems in their institution (Cohen, 2005). Therefore, it is important for university libraries to understand the factors that contribute to their personnel's use of information systems, especially for mandatory use.

Compeau and Higgin (1995) suggest that individuals would use an information system if they could see potentially positive value associated with such use.

Previous research on library personnel's use of information system includes Ajiferuke (2003), Cohen (2005), Egunjobi \& Awoyemi (2012), Rao \& Babu (2001), and Ryan, Porter, \& Miller, 2010). However, there is dearth of studies on KOHA library management software (an information system widely used in Nigeria), and the influence of social cognitive theory has rarely been considered.

This study therefore uses social cognitive theory to study library personnel's use of the KOHA library management system. Specifically, it is aimed to analyze the relationship between library personnel's actual system use and sources of computer self-efficacy and outcome expectancy. The purpose of this research is also to empirically evaluate a theoretical model about mandatory use of the KOHA library management software, derived from the social cognitive theory.

\section{Social Cognitive Theory}

Acceptance of an information system depends on whether employees believe that the information system will benefit them. Prediction of employee beliefs for future computing use can be based on social cognition theory (Bandura, 1982; 1986). Social cognition theory links an individual's cognitive states to a variety of affective and behavioral outcomes (Staples, Hulland, \& Higgins, 1998). The cognitive states are self-efficacy and outcome expectancy. Self-efficacy and outcome expectancy are cognitive factors that contribute to individuals' control of their behavior (Bandura, 1986).

Self-efficacy is an individual's belief that he or she possesses the skills and abilities to successfully perform a specific task (Bandura, 1986). Self-efficacy beliefs contribute significantly to the level and quality of human functioning. Those who have a strong belief in their capabilities exert greater effort in completing the task, and they show much persistence and resilience to failure. Computer self-efficacy, a specific self-efficacy, is a belief of one's capability to use computers (Compeau \& Higgins, 1995). Individuals with little confidence in their ability to use computers might perform more poorly on computer-based tasks. It is not about the skills individuals possess, but about their judgment of what they can do with the skills they have. 
Outcome expectancy is an individual's belief that, by accomplishing the task, a desired outcome is attained (Bandura 1986). In other words, it is one's belief that the behavior will produce certain outcomes and those outcomes are of value. Individuals act on their beliefs about what they can do, as well as their beliefs about the likely outcome of performance.

Furthermore, social cognitive theory purported that self-efficacy and outcome expectation are derived directly from four sources. These sources are: performance accomplishment in the past (previous experience), modeled exposure (vicarious experience of observing others performing the same task), emotional or physiological arousal (state of the user in anticipation of doing a task such as system usability), and social persuasion (verbal encouragement from supportive management). The four sources impact task performance through self-efficacy and outcome expectancy.

The user's past computer experience indicates his or her mastery of the task. Some researchers (Barbeite \& Weiss, 2004; Havelka, 2003) studied the effect of previous experience of computer use and evaluated the impact of demographic factors on self-efficacy. Through modeled exposure, vicarious experience is gained by observing and modeling after the behaviors of other people who have previously completed the intended task and, as a result, the individual can improve his or her own performance (Eastin \& LaRose, 2000).

Emotional or physiological arousal is the state of a user in anticipation of system usability. Usability is the perceived ease of using the system. Usability is the measure of the quality of the user's experience when interacting with a system (Holms, 2002; Nielson, 2000). Usability is the extent to which a system enables users to achieve specified goals. Users rely on their state of emotional or physiological arousal in assessing the usability of the system. Stressful and taxing situations elicit emotional arousal that can affect the user's self-efficacy in coping with threatening situations. This is because high arousal influences performance. If users are at ease with a task, they feel confident and have high beliefs of self-efficacy. Self-efficacy will influence the persistence with which the user attempts to learn a new and difficult task. Usability impacts perceptions of self-efficacy and outcome expectancy (Bandura, 1977).

According to social cognitive theory, supportive management such as social pressures and persuasion encourage employees to use the information system, especially when such system use in the organization is mandatory. Those given supportive management to perform a task were found to have greater self-efficacy (Bandura, 1977; 1986).

\section{The Research Model and Hypotheses}

Based on the literature, a model was derived from social cognitive theory (Bandura, 1982), developed and used for this research. Specifically, the theoretical model links previous computer experience, usability and supportive management to both outcome expectancy and self-efficacy. Self-efficacy is also predicted by the model to impact outcome expectancy. Both self-efficacy and outcome expectancy are assumed to impact actual system use. The theoretical model is shown in Figure 1.

It is important to note that in this model emotional/physiological arousal is substituted with usability and vicarious experience was not included. The decision of excluding vicarious experience is based on consideration of the fact that the library personnel included in this study, as users of the information system, typically work alone in different universities, and therefore modeling experience may not be possible. Derivation of hypotheses from this model, with support of previous research findings, is discussed below. 


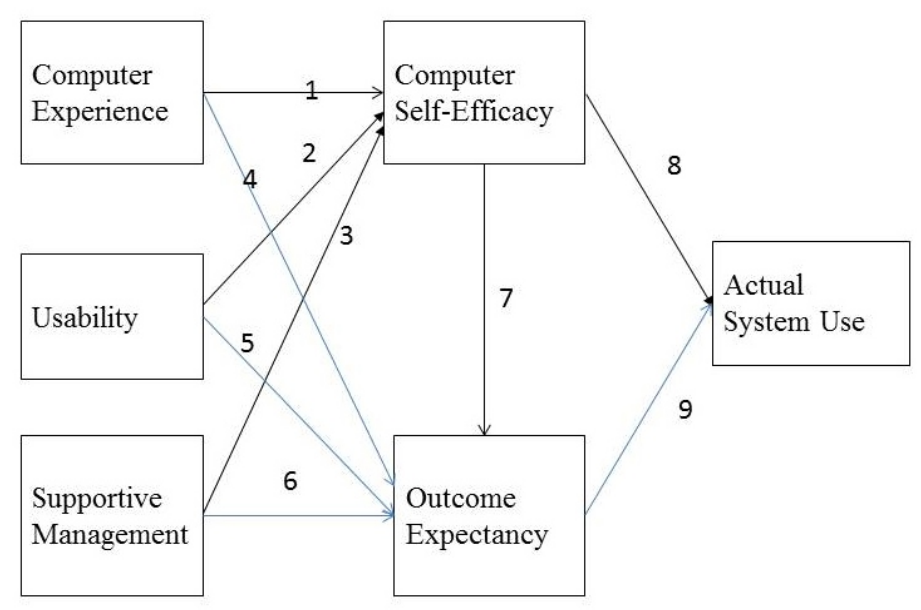

Figure 1. Proposed Research Model (with hypotheses indicated by the arrows)

Previous studies (Hasan, 2003; Havelka, 2003; Liu, 2003; Wilson \& Shrock, 2001) found that computer experience in certain areas of computer programming and graphic applications was correlated with higher self-efficacy. Thus the hypothesis below:

H1: Computer experience has a positive influence on computer self-efficacy.

The easier a system is to use, the more likely an individual will use it (Venkatesh, Morris, Davis, $\&$ Davis, 2003). The more favorable an individual perceives the system in terms of usability, the more confident he or she feels about performing the task (Liu, 2003). System usability influences self-efficacy and is related to the perception of task completion. Thus the hypothesis below:

H2: Usability has a positive influence on computer self-efficacy.

Researchers have also argued that by providing management support to computer users, their ability is improved, which in turn results in perception of higher self-efficacy (Compeau \& Higgins, 1995; Igbaria \& Iivari, 1995; Venkatesh, 2000). Thus the hypothesis below:

H3: Supportive management has a positive influence on computer self-efficacy.

Past experience leads to expectation of usefulness of outcomes from completing the task (BakerEveleth \& Stone, 2008). Thus the hypothesis below:

H4: Computer experience has a positive influence on outcome expectancy.

Usability improves an individual's perception of the value of completing the task, i.e., outcome expectancy (Baker-Eveleth \& Stone, 2008; Compeau \& Higgins, 1995; Williamson, Lepak, \& King, 2003). Thus the hypothesis below:

H5: Usability has a positive influence on outcome expectancy.

Supportive management occurs when employees are guided by their superior or peers, or when management suggests that they have the capability to complete the expected task. One intended outcome of implementing an information system is to have the employees use it. Supportive management can make the difference in successful task completion and adoption of the system through influencing the user's expectation and perception of value from task completion (Henry $\&$ Stone, 1995). Thus the hypothesis below:

H6: Supportive management has a positive influence on outcome expectancy.

Self-efficacy and outcome expectancy have separate impacts on user behaviors. However, selfefficacy typically has a larger effect than outcome expectancy (Bandura, 1986). Generally, self- 
efficacy has a direct impact on outcome expectancy (Stone \& Henry, 2003). Thus the hypothesis below:

H7: Computer self-efficacy has a positive influence on outcome expectancy.

In the past, social cognitive theory used self-efficacy to explain individuals' reactions to information technologies (Bandura, 1986; Potosky, 2002). Several studies have shown the effect of computer self-efficacy on computer-related behaviors. Computer self-efficacy is shown to be positively related to performance during computer training (Sam, Othman \& Nordin 2005; Webster \& Martocchio, 1992). Students' confidence about their computer skills affects their willingness to learn about computer technology (Zhang \& Espinoza, 1998). Thus the hypothesis below:

H8: Computer self-efficacy has a positive influence on actual system use.

Several recent studies reported that outcome expectation affects computer use. Outcome expectancy is considered an important factor in explaining individual behaviors in the information system (Bandura, 1986; Compeau \& Higgins, 1995). Previous research findings imply that outcome expectancy is a very important cognitive factor in the user's control of behaviors, and therefore it may play an important role in predicting and explaining performance (Kwahk \& Oh, 2009). Thus the hypothesis below:

H9: Outcome expectancy has a positive influence on actual system use.

\section{Method}

In order to test the model depicted in Figure 1, a questionnaire survey was conducted in June 2012 to collect data. Participants were assured of their confidentiality, and they voluntarily took part in the study.

\section{Participants}

The survey was hand delivered by a research assistant to the libraries of five private universities in south-western Nigeria, and then distributed to 65 library professionals. In total, 61 of them completed and returned the survey, yielding a response rate of $93.85 \%$. All responses were valid and included in the analysis. Of those who responded to the survey, $28(45.9 \%)$ were library assistants, 10 (16.4\%) were library officers, 20 (32.8\%) were librarians, and $3(4.9 \%)$ were library system analysts.

\section{Justification for Small Sample Size}

The number of library personnel working in private universities in Nigeria was small to start with. The KOHA software (version 3.0.1) was utilized for library operation (acquisition, cataloguing, serials control, and circulation) in some universities in Nigeria (Egunjobi \& Awoyemi, 2012; Lawal, 2000), but not in all. The limitation of study scope to library personnel's mandatory use of the KOHA system further reduced the sampling pool. All this made random sampling unrealistic, and consequently a purposive sampling method was adopted.

\section{Instrument}

The questionnaire was essentially an assembly of factor-specific measuring instruments developed by previous researchers, as explained later in this subsection. It was organized into two sections. The first section included questions on demographics such as computer experience, age, sex, and job status. The second section included five instrumental scales (made of either 5- or 7point Likert-scale questions) previously developed by other researchers to measure specific factors (usability, supportive management, outcome expectancy, computer self-efficacy, and actual system use). 
Influence of User Efficacy \& Expectation on System Use

Usability of system (US) was measured with the scale developed by Brooke (1996). The ten-item scale measured effectiveness, efficiency, and satisfaction with which user achieve specified task/goals. Bangor, Kortum and Miller (2008) reported Cronbach's alpha of 0.91 for the scale's reliability. Supportive management (SM) was measured with the five-item scale developed by Kahn (1990) who reported a reliability coefficient score of 0.83 . The internet self-efficacy scale developed by Eastin and LaRose (2000) was adapted for measuring computer self-efficacy (CS). The scale has eight items, each of which is preceded by the phrase "I feel confident". The authors reported Cronbach's alpha of 0.93 for its reliability. Outcome expectancy (OE) was measured with a two-item scale constructed by Wong (2005) who reported Cronbach's alpha of 0.81 for its reliability. The scale was adapted to measure participants' degree of confidence that using the KOHA library management software would lead to positive outcome.

Actual system use was measured in three dimensions: immersion, reinvention, and learning (Barki, Titah \& Boffo, 2007; Burton-Jones \& Straub, 2006). The dimension of immersion (IM) (Agarwal \& Karahanna, 2000; Burton-Jones \& Straub, 2006) includes four items, each of which is preceded by the phrase "When I use KOHA library management software". Kwahk and Oh (2009) reported Cronbach's alpha of 0.94 for this part. The dimension of reinvention (RI) (Barki, Titah \& Boffo, 2007; Rice \& Rogers, 1980) includes four items, each of which is preceded by the phrase "When I use KOHA library management software, I exert myself to". The dimension of learning (LE) (Barki, Titah \& Boffo, 2007; Rice \& Rogers, 1980) includes four items. For the last two dimensions (reinvention and learning), Kwahk and Oh (2009) reported Cronbach's alpha of 0.95 for reliability.

All of the aforementioned scales were adapted for use in this study and factor analyzed (see Appendix). The total correlation of items in each scale was above 0.34, and therefore all items contributed to the measure significantly (Rust \& Golombok, 1995). Further, they all had acceptable Cronbach's alpha values (Nunnally, 1967).

\section{Statistical Analysis}

Survey responses were manually coded into a SPSS data file, and the SPSS software was used for statistical analysis. Multiple regression analysis was conducted to assess the model and the impact of each variable in determining actual system use, by virtue of testing the formulated hypotheses. Pearson moment coefficient correlation was used to establish relationships among variables in the model.

\section{Results}

The first three hypotheses ( $\mathrm{H} 1, \mathrm{H} 2$ and $\mathrm{H} 3)$ state that computer experience, usability and supportive management each has a positive influence on computer self-efficacy respectively. Each of these hypotheses contains the same dependent variable, and therefore the same regression model was used to evaluate each hypothesis. Specifically, the hypotheses were tested by regressing computer experience ( $\mathrm{H} 1)$, usability $(\mathrm{H} 2)$, and supportive management $(\mathrm{H} 3)$ on computer self-efficacy. The results (as summarized in Table 1) revealed significant support of $\mathrm{H} 2$ $(\beta=0.18, p<.05)$ and $\mathrm{H} 3(\beta=0.77, p<.01)$, but not $\mathrm{H} 1$, meaning that usability and supportive management have influence on computer self-efficacy.

The hypotheses H4, H5 and H6 state that computer experience, usability, and supportive management each have positive influence on outcome expectancy respectively. Again, each of these hypotheses contains the same dependent variable, and therefore the same regression model was used. The hypotheses were tested by regressing computer experience (H4), usability (H5), and supportive management (H6) on outcome expectancy. The results are summarized in Table 2, showing no significant support of any of these hypotheses. 
Table 1. Regression Analysis of Computer Experience, Usability and Supportive Management on Computer Self-Efficacy

\begin{tabular}{|l|l|l|l|l|l|}
\hline Variable & $\boldsymbol{\beta}$ & Std. error & $\mathbf{t}$ & $\boldsymbol{p}$ & $\mathbf{R}^{\mathbf{2}}$ \\
\hline Computer Experience & -0.03 & 0.04 & -0.41 & $>.05$ & 0.80 \\
Usability & 0.18 & 0.20 & 2.24 & $<.05$ & \\
Supportive Management & 0.77 & 0.13 & 9.54 & $<.01$ & \\
\hline
\end{tabular}

Table 2. Regression Analysis of Computer Experience, Usability and Supportive Management on Outcome Expectancy

\begin{tabular}{|l|l|l|l|l|l|}
\hline Variable & $\boldsymbol{\beta}$ & Std. error & $\mathbf{t}$ & $\boldsymbol{p}$ & $\mathbf{R}^{\mathbf{2}}$ \\
\hline Computer Experience & 0.21 & 0.02 & 1.69 & $>.05$ & 0.19 \\
Usability & 0.30 & 0.12 & 1.87 & $>.05$ & \\
Supportive Management & 0.12 & 0.80 & 7.30 & $>.05$ & \\
\hline
\end{tabular}

The hypothesis $\mathrm{H} 7$ states that computer self-efficacy has a positive influence on outcome expectancy. Computer self-efficacy was regressed on outcome expectancy. The results (shown in Table 3) gave significant support of $\mathrm{H} 7(\beta=0.33, p<.01)$, meaning that computer self-efficacy has an influence on outcome expectancy.

Table 3: Regression Analysis of Computer Self-efficacy on Outcome Expectancy

\begin{tabular}{|l|l|l|l|l|l|}
\hline Variable & $\boldsymbol{\beta}$ & Std. error & $\mathbf{t}$ & $\boldsymbol{p}$ & $\mathbf{R}^{2}$ \\
\hline Computer Self Efficacy & 0.33 & 0.19 & 10.36 & $<.01$ & 0.11 \\
\hline
\end{tabular}

The hypotheses $\mathrm{H} 8$ and $\mathrm{H} 9$ state that computer self-efficacy and outcome expectancy each has a positive influence on actual system use respectively. These hypotheses contain the same dependent variable, and therefore the same regression model was used to evaluate each hypothesis. The hypotheses were tested by regressing both computer self-efficacy (H8) and outcome expectancy (H9) on actual system. The results (shown in Table 4) gave support of only H8 $(\beta=0.60, p<.01)$, meaning that computer self-efficacy has an influence on actual system use.

Table 4: Regression Analysis of Computer Self-Efficacy and Outcome Expectancy on Actual System Use

\begin{tabular}{|l|l|l|l|l|l|}
\hline Variable & $\boldsymbol{\beta}$ & Std. error & $\mathbf{t}$ & $\boldsymbol{p}$ & $\mathbf{R}^{\mathbf{2}}$ \\
\hline Computer Self-efficacy & 0.60 & 0.04 & 5.98 & $<.01$ & 0.48 \\
Outcome Expectancy & 0.19 & 0.13 & 1.87 & $>.05$ & \\
\hline
\end{tabular}




\section{The Structural Model Results}

Evaluation of the theoretical model was done by statistically testing the nine hypotheses (H1 through H9) with the survey data, and the results of hypothesis testing are summarized in Table 5, for ease of reference. Six of the nine hypotheses derived from the model were strongly supported.

Table 5: Summary of hypotheses testing $(* p<.05 ; * * p<.01)$

\begin{tabular}{|l|l|l|}
\hline No. & \multicolumn{1}{|c|}{ Statement of Hypothesis } & Supported \\
\hline H1 & Computer experience has positive influence on computer self-efficacy. & No \\
H2 & Usability has positive influence on computer self-efficacy. & Yes** \\
H3 & supportive management has positive influence on computer self-efficacy & Yes** \\
H4 & Computer experience has positive influence on outcome expectancy. & No \\
H5 & Usability has positive influence on outcome expectancy. & Yes** \\
H6 & Supportive management has positive influence on outcome expectancy. & Yes* \\
H7 & Computer self-efficacy has positive influence on outcome expectancy. & Yes** \\
H8 & Computer self-efficacy has positive influence on actual system use & Yes** \\
H9 & Outcome expectancy has positive influence on actual system use & No \\
\hline
\end{tabular}

Figure 1 shows the path analysis and path coefficients, representing standardized regression weights or correlation coefficients between two variables. Regression weight (r), within the range of $(-1.00,1.00)$, indicates both the direction and strength of the linear relationship between two variables. The significance level of regression coefficients is 0.05 (Compeau \& Higgins, 1995).

The $\mathrm{R}^{2}$ values show strong support for the model, representing the percentage of variance in the particular dependent variable that is explained by the antecedent variables. Specifically, $80 \%$ of variance is explained by computer self-efficacy, $19 \%$ by outcome expectancy, and $48 \%$ by actual system use.

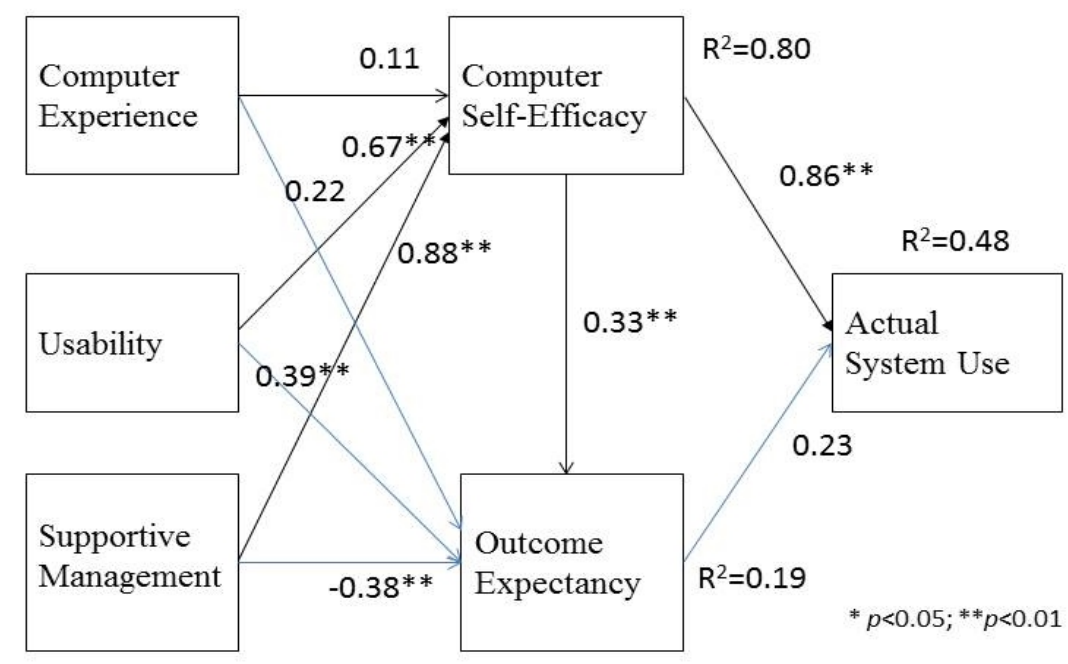

Figure 2. Research Model with Correlation Coefficients and Squared Multiple Regressions 


\section{Discussion}

All of the hypothesized factors (H1 through H9) contributed strong variance to actual system use, supporting Bandura's (1977) theory that cognitive process plays an important role in the acquisition, regulation, and retention of new behaviors. Actual system use is a behavior of three dimensions: immersion (Burton-Jones \& Straub, 2006), reinvention, and learning (Barki, Titah, \& Boffo, 2007). There is an element of interaction with technology between the user and the system, development of fit between the task and the system, and the user's search for knowledge to improve skills required to use the system.

The finding that usability has a positive influence on computer self-efficacy (H2) supports Liu's (2003) observation that the more favorable an individual perceives the usability of a system, the more confident he or she feels about performing the task. Stressful and taxing situation elicits emotional arousal that can affect the user's self-efficacy in coping with the threatening situation. This is because high arousal influences performance. If the user is at ease with the system's usability, he or she would feel confident and have higher belief of self-efficacy.

The finding that supportive management has a positive influence on computer self-efficacy (H3) corroborates the observations by some researchers (Compeau \& Higgins, 1995; Igbaria \& Iivari, 1995; Venkatesh, 2000). Provision of management support to computer users improves their ability and judgment of self-efficacy.

Only two variables - usability and supportive management - were found to influence computer self-efficacy independently. Both usability and supportive management are identified as sources influencing the cognitive process of self-efficacy (Bandura, 1977). The more the user depends on and experiences of the sources, the greater the change in his or her self-efficacy. The sources of self-efficacy can affect the persistence and performance of completing a task.

H7 states that computer self-efficacy has a positive influence on outcome expectancy. The findings of this study show that self-efficacy typically has a larger effect than outcome expectancy does, and that self-efficacy has a direct impact on outcome expectancy, which supports Bandura (1986) and Stone \& Henry's (2003) claims.

H8 states that computer self-efficacy has a positive influence on actual system use. The results of this study support Sam, Othman \& Nordin (2005) and Webster \& Martocchio's (1992) claim that computer self-efficacy is positively related to performance. This finding also corroborates Bandura's (1986) theory that self-efficacy is a cognitive factor in individuals' control of their behaviors. Self-efficacy impacts users' learning and their effort to immerse on a task, and it affects their choice of goals as well.

All these findings suggest that the KOHA software meets library personnel's specifications and has the ability to fulfill their needs effectively and efficiently. There is social persuasion from the management for them to make mandatory use of the KOHA software. Library personnel have the capability and are confident in their ability to use computers and to perform well with the KOHA software. The findings also have implications for software developers to improve the usability of the KOHA software. Management should increase support of users in adapting to the KOHA software and offer training to build up their confidence for successful adjustment.

\section{Conclusion}

The findings of this study indicate that usability, supportive management, and computer selfefficacy strongly influence library personnel's actual use of the KOHA software system. The results show that computer self-efficacy has influence on outcome expectancy. Computer selfefficacy takes precedence over other variables in influencing actual system use. This study gives empirical support of the structural model, and in turn to social cognitive theory. 
One major weakness of this study is the small sample size for gathering survey data. In addition, the survey scope was limited to the library personnel in a few private universities in southwestern Nigeria that make use of the KOHA software. Future research should employ a larger sample of library personnel from more universities (public and private alike) that have the KOHA software in use. The time frame of study also needs be increased. Actual system use may be measured as a holistic factor instead of separately in terms of its three underlying dimensions.

\section{References}

Agarwal, R., \& Karahanna, E. (2000). Time flies when you're having fun: Cognitive absorption and beliefs about information technology usage. MIS Quarterly, 24(4), 665-694.

Ajiferuke, I. (2003). Role of information professional in knowledge management programs: Empirical evidence from Canada. Informing Science Journal, 6, 247-257. Retrieved from http://www.inform.nu/Articles/Vol6/v6p247-257.pdf

Baker-Eveleth, L., \& Stone, R. W. (2008). Expectancy theory and behavioral Intentions to use computer applications. Interdisciplinary Journal of Information, Knowledge, and Management 3, 135-146. Retrieved from http://www.ijikm.org/Volume3/IJIKMv3p135-146Baker362.pdf

Bandura, A. (1977). Self-efficacy: Toward a unifying theory of behavioral change. Psychological Review, 84(2), 191-215.

Bandura, A. (1982). Self-Efficacy mechanism in human agency. American Psychologist, 37, 122-147.

Bandura, A. (1986). Social foundation of thought and action: A social cognitive theory. New Jersey: Prentice-Hall.

Bangor, A., Kortum, P .T., \& Miller, J. T. (2008). An empirical evaluation of the system usability scale. International Journal of Human Computer Interaction, 24(6), 575-594.

Barki, H., Titah, R., \& Boffo, C. (2007). Information system use-related activity: An expanded behavioural conceptualization of individual-level information system use. Information Systems Research, 18(2), 173-192.

Barbeite, F. G., \& Weiss, E. M. (2004). Computer self-efficacy and anxiety scales for an internet sample: testing measurement equivalence of existing measures and development of new scales. Computers in Human Behavior, 20, 1-15.

Beaudry, A., \& Pinsonneault, A. (2005). Understanding user responses to information technology: A coping model of user adaptation. MIS Quarterly, 29(3), 493-524.

Brooke, J. (1996) SUS: A “quick and dirty” usability scale. In P. W. Jordan, B. Thomas, B. A. Weerdmeerster, \& I. L. McClelland (Eds.). Usability evaluation in industry (pp. 189-194). London: Taylor \& Francis.

Burton-Jones, A., \& Straub, D.W. (2006). Reconceptualizing system usage: An approach and empirical test. Information Systems Research, 17(3), 228-246.

Cohen, A. M. (2005). UCLA community college review: Why practitioners and researchers ignore each other (even when they are same person) Community College Review, 331(1), 51-62.

Compeau, D. R., \& Higgins, C. A. (1995). Computer self-efficacy: Development of a measure and initial test. MIS Quarterly, 19(2), 189-211.

Eastin, M. S., \& LaRose, R. (2000). Internet self efficacy and the psychology of the digital divide. Journal of Computer Mediated Communication, 6(1). Retrieved January 19, 2008 from http://www.asusc.org/jcmc/vol6/issue1/eastin.html

Egunjobi, R. A., \& Awoyemi, R. A. (2012). Library automation with Koha. Library Hi Tech News, 29(3), $3-13$. 
Hasan, B. (2003). The influence of specific computer experiences on computer self-efficacy beliefs. Computers in Human Behavior, 19(4), 443-450.

Havelka, D. (2003). Predicting software self-efficacy among business students: A preliminary assessment. Journal of Information Systems Education, 14(2), 145.

Henry, J. W., \& Stone, R. W. (1995). End-user perceptions of a computer-based medical information system's impact on patient care. Journal of Health Information Management Research, 3(2), 1-16.

Holms, M. (2002). Web usability and navigation. New York: McGraw-Hill.

Igbaria, M., \& Iivari, J. (1995). The effects of self-efficacy on computer usage. Omega, 23(6), 587-605.

Kahn, W. (1990). Psychological conclusion of personal engagement and disengagement at work. Academy of Management Journal, 33, 692-724.

Kwahk, K., \& Oh, S. (2009) Examining the effect of user expectations on system use activity. Paper Presented at the $17^{\text {th }}$ European Conference on Information systems ECIS Verona.

Lawal, O. (2000). Academic factors and staff appraisal in Nigeria university libraries. In S. Amanquah (Ed.), SCAULWA Proceedings (pp. 60-76). Kumasi: Kumasi University Press.

Liu, L. (2003). Usability and efficacy reactions to object-orientation: The impact prior knowledge. Proceedings (pp.70-74) of the Second Annual Workshop on HCI Research in MIS, Seattle: WA.

Nielson, J. (2000). Designing web usability: The practice of simplicity. Indianapolis: New Riders.

Nunnally, J. (1978). Psychometric methods (2nd ed.). New York: McGraw-Hill.

Potosky, D. (2002). A field study of computer efficacy beliefs as an outcome of training: The role of computer playfulness, computer knowledge, and performance during training. Computers in Human Behavior, 18(3), 241-255.

Rao, K. N., \& Babu, K. H. (2001) Role of librarian in internet and world wide web environment. Informing Science Journal, 4(1), 25-34. Retrieved from http://www.inform.nu/Articles/Vol4/v4n1p025-034.pdf

Rawstorne, P., Jayasuriya, R., \& Caputi, (1998). An integrative model of information systems use in mandatory environments. Paper Presented at the International Conference on Information Systems, Helsinki, Finland.

Rawstorne, P., Jayasuriya, R., \& Caputi, P. (2000). Issues in predicting and explaining usage behaviours with the technology acceptance model and the theory of planned behaviour: When usage is mandatory. Paper presented at the International Conference on Information Systems, Brisbane, Australia.

Rice, R.E., \& Rogers, E.M. (1980). Reinvention in the innovation process. Knowledge: Creation, Diffusion, Utilization, 1(4), 499-514.

Rust, J., \& Golombok, S. (1995). Modern psychometric: The science of psychological assessment. New York: Routledge.

Ryan, J., Porter, M., \& Miller, R. (2010). Academic library services in virtual worlds: An examination of the potential library services in immersive environments. Journal of Information Technology Education, Innovations in Practice, 9, 253-275. Retrieved from http://www.jite.org/documents/Vol9/JITEv9IIPp253-275Ryan867.pdf

Sam, K. H., Othman, A. E. A., \& Nordin, S. Z. (2005). Computer self-efficacy, computer anxiety and attitude toward the internet: A study among undergraduate in Unimas. Educational Technology and Society, 8(4), 205-219.

Staples, D. S., Hulland, J. S., \& Higgins, C. A. (1998). A self-efficacy theory explanation for the management of remote workers in virtual organizations. Journal of Computer Mediated Communication, 3(4). Retrieved January 19, 2008 from http://www.ascusc.org/jcmc/vo13/issue4/wiesenfeld.html 
Stone, R. W., \& Henry, J. W. (2003). The roles of computer self-efficacy and outcome expectancy in influencing the computer end-user's organizational commitment. Journal of End User Computing, 15(1), 38-53.

Torkzadeh, G., \& Koufteros, X. (1994). Factorial validity of a computer self-efficacy scale and the impact of computer training. Educational and Psychological Measurement, 54(3), 813-921.

Venkatesh, V. (2000). Determinants of perceived ease of use: Integrating control, intrinsic motivation and emotion into the technology acceptance model. Information System Research, 11(4), 342-365.

Venkatesh, V., Morris, M., Davis, G. B., \& Davis, F. D. (2003). User acceptance of information technology: Towards a unified view. MIS Quarterly, 27(3), 425-478.

Webster, J., \& Martocchio, J. J. (1992). Microcomputer playfulness: development of a measure with workplace implications, MIS Quarterly, 16(2), 201-226.

Williamson, I. O., Lepak, D. P., \& King, J. (2003). The effect of company recruitment website orientation on individuals perceptions of organizational effectiveness. Journal of Behaviour, 63(2) 242-263.

Wilson, B. C., \& Shrock, S. (2001). Contributing to success in an introductory computer science course: A study of twelve factors. ACM SIGCSE Bulletin, 33(1), 184-188.

Wong, K. F. E. (2005). The role of risk in making decisions. Applied Psychology: An International Review, 54(4), 584-607.

Zhang, Y., \& Espinoza, S. (1998). Relationships among computer self-efficacy, attitudes toward computers and desirability of learning computer skills. Journal of Research on Technology in Education, 30(4), 420-436. 


\section{Appendix: Factor and Reliability Analysis}

\begin{tabular}{|c|c|c|c|}
\hline & Questionnaires items & $\begin{array}{l}\text { Factor } \\
\text { loadings }\end{array}$ & $\begin{array}{l}\text { Item-total } \\
\text { correlation }\end{array}$ \\
\hline \multicolumn{4}{|c|}{ Factor 1: Usability (US) $($ Eigen value $=3.40 ;$ Cronbach alpha $=0.78)$} \\
\hline US 1 & I think that I would like to use this system frequently & 0.90 & 0.75 \\
\hline US 2 & I found the system unnecessarily complex & 0.72 & 0.54 \\
\hline US 3 & I thought the system was easy to use & 0.40 & 0.65 \\
\hline US 4 & $\begin{array}{l}\text { I think that I would need the support of a technical person } \\
\text { to be able to use this system }\end{array}$ & 0.80 & 0.72 \\
\hline US 5 & $\begin{array}{l}\text { I found the various functions in this system were well } \\
\text { integrated }\end{array}$ & 0.86 & 0.62 \\
\hline US 6 & I thought there was too much inconsistency in this system & 0.86 & 0.58 \\
\hline US 7 & $\begin{array}{l}\text { I would imagine that most people would learn to use this } \\
\text { system very quickly }\end{array}$ & 0.85 & 0.71 \\
\hline US 8 & I found the system very cumbersome to use & 0.72 & 0.77 \\
\hline US 9 & I felt very confident using the system & 0.92 & 0.75 \\
\hline US 10 & $\begin{array}{l}\text { I needed to learn a lot of things before I could get going } \\
\text { with this system }\end{array}$ & 0.47 & 0.70 \\
\hline \multicolumn{4}{|c|}{ Factor 2: Supportive Management $(\mathbf{S M})($ Eigen value $=3.61 ;$ Cronbach alpha $=0.90)$} \\
\hline SM 1 & $\begin{array}{l}\text { My boss is flexible about how I accomplish my job } \\
\text { objectives }\end{array}$ & 0.68 & 0.82 \\
\hline SM 2 & $\begin{array}{l}\text { My manager is supportive to my ideas and ways of getting } \\
\text { done }\end{array}$ & 0.83 & 0.91 \\
\hline SM 3 & My boss gives me the opportunity to do my job as I see fit & 0.75 & 0.87 \\
\hline SM 4 & $\begin{array}{l}\text { I am careful in taking responsibility because my boos is } \\
\text { often critical of new ideas }\end{array}$ & 0.51 & 0.72 \\
\hline SM 5 & $\begin{array}{l}\text { I can trust my boss to back up on decisions I make in the } \\
\text { field }\end{array}$ & 0.85 & 0.92 \\
\hline \multicolumn{4}{|c|}{ Factor 3: Computer Self-Efficacy $($ CS $)($ Eigen value $=6.01 ;$ Cronbach alpha $=0.95)$} \\
\hline & I feel confident: & & \\
\hline CS 1 & $\begin{array}{l}\ldots \text { in understanding terms/words relating to computer } \\
\text { hardware }\end{array}$ & 0.81 & 0.90 \\
\hline CS 2 & $\begin{array}{l}\text {... in understanding terms/words relating to computer } \\
\text { software }\end{array}$ & 0.79 & 0.89 \\
\hline CS 3 & ... describing functions of computer hardware & 0.92 & 0.96 \\
\hline CS 4 & ... trouble-shooting computer problems & 0.72 & 0.84 \\
\hline CS 5 & $\begin{array}{l}\text {... explaining why a task will not run on the computer to } \\
\text { gather data }\end{array}$ & 0.79 & 0.88 \\
\hline CS 6 & ... using the computer to gather data & 0.86 & 0.93 \\
\hline CS 7 & $\begin{array}{l}\text {... learning advanced skills within a specific computer } \\
\text { problem }\end{array}$ & 0.77 & 0.87 \\
\hline CS 8 & ... turning to computer expert when help is needed & 0.34 & 0.63 \\
\hline
\end{tabular}




\begin{tabular}{|c|c|c|c|}
\hline \multicolumn{4}{|c|}{ Factor 4: Outcome Expectation $(\mathbf{O E})($ Eigen value $=1.64 ;$ Cronbach alpha $=0.80)$} \\
\hline \multirow[b]{2}{*}{ OE 1} & \multicolumn{3}{|l|}{ When I use KOHA system: } \\
\hline & $\begin{array}{l}\text { How likely will the system increase usefulness of } \\
\text { performing the task }\end{array}$ & 0.82 & 0.90 \\
\hline OE 2 & $\begin{array}{l}\text { How likely will the system increase my sense of } \\
\text { accomplishment }\end{array}$ & 0.82 & 0.91 \\
\hline \multicolumn{4}{|c|}{ Factor 5: Immersion $(\mathbf{I M})($ Eigen value $=3.43 ;$ Cronbach alpha $=0.94)$} \\
\hline & \multicolumn{3}{|l|}{ When I use KOHA system, } \\
\hline IM 1 & I am able to block out all other distractions. & 0.84 & 0.91 \\
\hline IM 2 & I feel totally immersed in what I am doing. & 0.86 & 0.88 \\
\hline IM 3 & I feel completely absorbed in what I am doing. & 0.94 & 0.95 \\
\hline IM 4 & My attention does not get diverted very easily & 0.79 & 0.87 \\
\hline \multicolumn{4}{|c|}{ Factor 6: Reinvention $(\mathbf{R I})($ Eigen value $=3.54 ;$ Cronbach alpha $=0.96)$} \\
\hline & \multicolumn{3}{|l|}{ When I use KOHA system, I exert myself to } \\
\hline RI 1 & $\begin{array}{l}\text { Find improvements in the system's functionalities and } \\
\text { interface. }\end{array}$ & 0.88 & 0.89 \\
\hline RI 2 & Modify my tasks so that it better fits the system. & 0.82 & 0.83 \\
\hline RI 3 & $\begin{array}{l}\text { Find improvements in the system so that it better fits my } \\
\text { tasks. }\end{array}$ & 0.94 & 0.93 \\
\hline RI 4 & $\begin{array}{l}\text { Be better fits between the system and my business } \\
\text { processes. }\end{array}$ & 0.90 & 0.95 \\
\hline \multicolumn{4}{|c|}{ Factor 7: Learning $(\mathbf{L E})($ Eigen value $=3.21 ;$ Cronbach alpha $=0.91)$} \\
\hline & \multicolumn{3}{|l|}{ When I use KOHA system, I exert myself to } \\
\hline LE 1 & $\begin{array}{l}\text { Have opportunities to communicate with colleagues or } \\
\text { specialists in order to better understand how KOHA system } \\
\text { operates on my own initiative. }\end{array}$ & 0.77 & 0.79 \\
\hline LE 2 & $\begin{array}{l}\text { Increase my knowledge and my mastery of KOHA system } \\
\text { on my own initiative. }\end{array}$ & 0.90 & 0.97 \\
\hline LE 3 & Learn KOHA system on my own initiative. & 0.76 & 0.81 \\
\hline LE 4 & Invest much effort in order to better use KOHA system. & 0.79 & 0.89 \\
\hline
\end{tabular}




\section{Biographies}

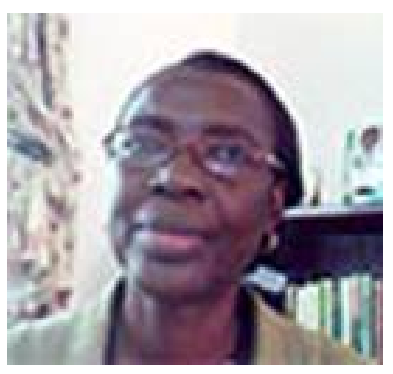

Olusola I. Akinbobola holds a doctorate degree in psychology from the University of Ibadan, Ibadan, Nigeria, specializing in industrial/organizational psychology. She is currently a lecturer in the Psychology Program at Redeemer's University, Nigeria. She formerly held managerial position in the banking industry. Her research interests include escalation of commitment and environmental attitudes. Dr Akinbobola is a senior member of International Economics Development Research Center (IEDRC) and a member of Chartered Institute of Personnel Management of Nigeria (CIPMN).

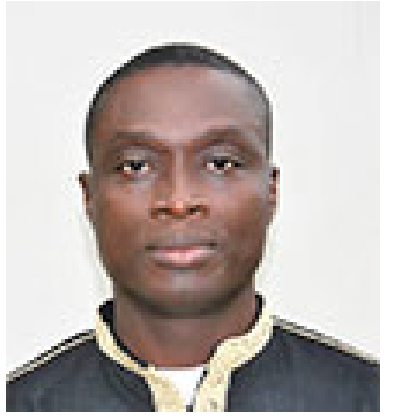

Akinniyi A. Adeleke is a Ph.D. student in the Department of Library, Archival and Information Studies, University of Ibadan. He holds a Bachelor degree in food science and technology from Obafemi Awolowo University, Ile-Ife. His research interest is in the area of knowledge management. He works as the librarian in charge of electronics resources management at the Redeemer's University, Nigeria. 